\title{
To the fauna of plume moths (Lepidoptera: Pterophoridae) of the Maluku islands with description of two new species of the genus Pteropborus Schäffer, 1766
}

\author{
К фауне пальцекрылок (Lepidoptera: Pterophoridae) \\ Молуккских островов с описанием двух новых видов из рода \\ Pterophorus Schäffer, 1766
}

\author{
P.Ya. Ustjuzhanin ${ }^{1,2^{*}}$, V.N. Kovtunovich ${ }^{3}$, A.N. Streltzov ${ }^{4}$ \\ П.Я. Устюжанин ${ }^{1,2^{*}}$, В.Н. Ковтунович ${ }^{3}$, А.Н. Стрельцов ${ }^{4}$
}

\footnotetext{
${ }^{1}$ Altai State University, Lenina 61. RF-656049 Barnaul, Russia. E-mail: petrust@mail.ru.

${ }^{2}$ Biological Institute, Tomsk State University, Lenina Prospekt 36, Tomsk 634050, Russia. E-mail: petrust@mail.ru.

${ }^{3}$ Moscow Society of Nature Explorers, Bolshaya Nikitskaya 2, Moscow 125009, Russia. E-mail: vasko-69@mail.ru.

${ }^{4}$ Herzen State Pedagogical University of Russia, Moika Emb. 48, Saint-Petersburg, 191186, Russia. E-mail: streltzov@mail.ru

1 Алтайский государственный университет, пр. Ленина 61, Барнаул 656049, Россия.

2 Томский государственный университет, пр. Ленина 33, Томск 634050, Россия.

${ }^{3}$ Московское общество испытателей природы, ул. Большая Никитская, 6 Москва, 103009 Россия.

${ }^{4}$ Российский государственный педагогический университет имени А. И. Герцена, наб. реки Мойки 48, Санкт-Петербург 191186 Россия.

* Corresponding author
}

KEY WORDS: Pterophoridae, Pterophorus, Indonesia, Maluku islands, new species, new data.

КЛЮЧЕВЫЕ СЛОВА: Pterophoridae, Pterophorus, Индонезия, Молуккские острова, новые виды, новые данные.

ABSTRACT. Basing on the materials from the British Museum (BMNH), we describe two new species of plume moths from the Maluku islands: Pterophorus dohertyi Ustjuzhanin et Kovtunovich sp.n. and Pterophorus shevnini Ustjuzhanin et Kovtunovich sp.n. According to the collections of O. Gorbunov, five species of Pterophoridae are listed as well, two of which turned out to be new for the Maluku islands.

РЕЗЮМЕ. По материалам Британского Музея (BMNH) из Молуккских островов описываются два новых вида пальцекрылок: Pterophorus dohertyi Ustjuzhanin et Kovtunovich sp.n. и Pterophorus shevnini Ustjuzhanin et Kovtunovich sp.n. Так же, по сборам О. Горбунова, приводятся 5 видов Pterophoridae, два из которых оказались новыми для Молуккских островов.

The Maluku islands are a group of islands located between Sulawesi and New Guinea. Most of the archipelago is covered with mountains and forests. The vegetation of these small islands is very various, pre- sented by tropical rainforests. A high level of endemism is characteristic of the Maluku islands. There were no special studies on plume moths of this region.

The genus Pterophorus in the Oriental region includes 15 species [Arenberger, 1989, 1995; Gielis, 2000, 2003; Ustjuzhanin et Kovtunovich, 2010, 2015]. Only one species of this genus was reported from the Maluku islands - Pterophorus niveus (Snellen, 1903) [Gielis 2000]. In the collection of British Museum we have found two more species of the genus Pterophorus, which turned to be new to science. Their holotypes are deposited in the collection of British Museum in London (BMNH). Moreover, according to the collections of O. Gorbunov, five species of Pterophoridae are listed as well, two of which turned out to be new for the Maluku islands (marked *).

\section{List of species}

*Deuterocopus atrapex Fletcher, 1910 Lanka).

How to cite this article: Ustjuzhanin P.Ya., Kovtunovich V.N., Streltzov A.N. 2020. To the fauna of plume moths (Lepidoptera: Pterophoridae) of the Maluku islands with description of two new species of the genus Pterophorus Schäffer 1766 // Russian Entomol. J. Vol.29. No.3. P.285-288. doi: 10.15298/rusentj.29.3.07 
Deuterocopus fervens Meyrick, 1913: 108. (Type locality: India). MATERIAL EXAMINED. 8 ex., Indonesia, N. Maluku, Obi. Id. Laiwui, $01^{\circ} 24^{\prime} \mathrm{S}, 127^{\circ} 38^{\prime} \mathrm{E}, \mathrm{h}-190 \mathrm{~m}, 26.1 \mathrm{i} .2017$, O. Gorbunov leg. DISTRIBUTION. India, Sri Lanka, Indonesia, Australia. NOTE. New to Indonesia.

\section{Deuterocopus socotranus Rebel, 1907}

Deuterocopus socotranus Rebel, 1907: 115. (Type locality: Yemen, Sokotra). Lanka).

Deuterocopus viticola Meyrick, 1911: 104. (Type locality: Sri

Deuterocopus triannulatus Meyrick, 1913: 107. (Type locality: Australia).

MATERIAL EXAMINED. 1 \%, Indonesia, N. Maluku, Obi. Id. Labuha, $01^{\circ} 20^{\prime} \mathrm{S}, 127^{\circ} 38^{\prime} \mathrm{E}, \mathrm{h}-15 \mathrm{~m}, 23$. ii.2017, O. Gorbunov leg.

DISTRIBUTION. Yemen, Oman, Japan, India, Sri Lanka, Thailand, Taiwan, Burma, Indonesia, New Guinea, Australia, Somalia, Uganda, Kenya, Nigeria, Republic of South Africa.

\section{Deuterocopus sp.}

MATERIAL EXAMINED. 1 ex., Indonesia, N. Maluku, Bacan Id. Laiwui, $00^{\circ} 39^{\prime} \mathrm{S}, 127^{\circ} 30^{\prime} \mathrm{E}, \mathrm{h}-118 \mathrm{~m}, 28 . \mathrm{ii} .2017$, O. Gorbunov leg.

NOTE. It was impossible to determine the species due to the lack of the abdomen in the specimen.

*Platyptiliodes niphadothysana (Diakonoff, 1952)

Fletcherella niphadothysana Diakonoff, 1952: 14. (Type locality: Indonesia, Irian Jaya).
MATERIAL EXAMINED. 9 ex. Indonesia, N. Maluku, Obi. Id. Labuha, $01^{\circ} 20^{\prime} \mathrm{S}, 127^{\circ} 38^{\prime} \mathrm{E}, \mathrm{h}-15 \mathrm{~m}, 1-3 . i i i .2017$, O. Gorbunov leg. DISTRIBUTION. Indonesia, Philippines, New Guinea. NOTE. New to the Maluku islands.

Pterophorus niveus (Snellen, 1903) Java).

Aciptilia nivea Snellen, 1903: 56. (Type locality: Indonesia,

MATERIAL EXAMINED. 1 \%, Indonesia, N. Maluku, Obi. Id. Labuha, $01^{\circ} 20^{\prime} \mathrm{S}, 127^{\circ} 38^{\prime} \mathrm{E}, \mathrm{h}-15 \mathrm{~m}, 23 . \mathrm{ii} .2017$, O. Gorbunov leg. DISTRIBUTION. Indonesia, Philippines, New Guinea.

Pterophorus dohertyi

Ustjuzhanin et Kovtunovich, sp.n.

Figs 1-2.

TYPE MATERIAL: Holotype, $\sigma^{7}$, (BMNH gen.pr. 22799), [Maluku Islands], Batian, Doherty, 1892. No. Walsingham Collection. B.M. 1910-427.

DESCRIPTION. External characters. Forehead covered with tightly clinging light-brown scales. Labial palpi straight, apically sharp, slightly shorter than longitudinal eye diameter. Antennae thin, yellowish-brown. Thorax and tegulae light-brown. Wingspan $17 \mathrm{~mm}$. Fore wings light-yellow, lobes deeply split. Distinct dark spot at cleft base. Three small dark brown points along costa of first lobe distally. Dark strokes and points on second lobe apically. Fringe inside cleft white, only distally with small portion of brownish hairs. Fringe along outer edge of second lobe also white, with two

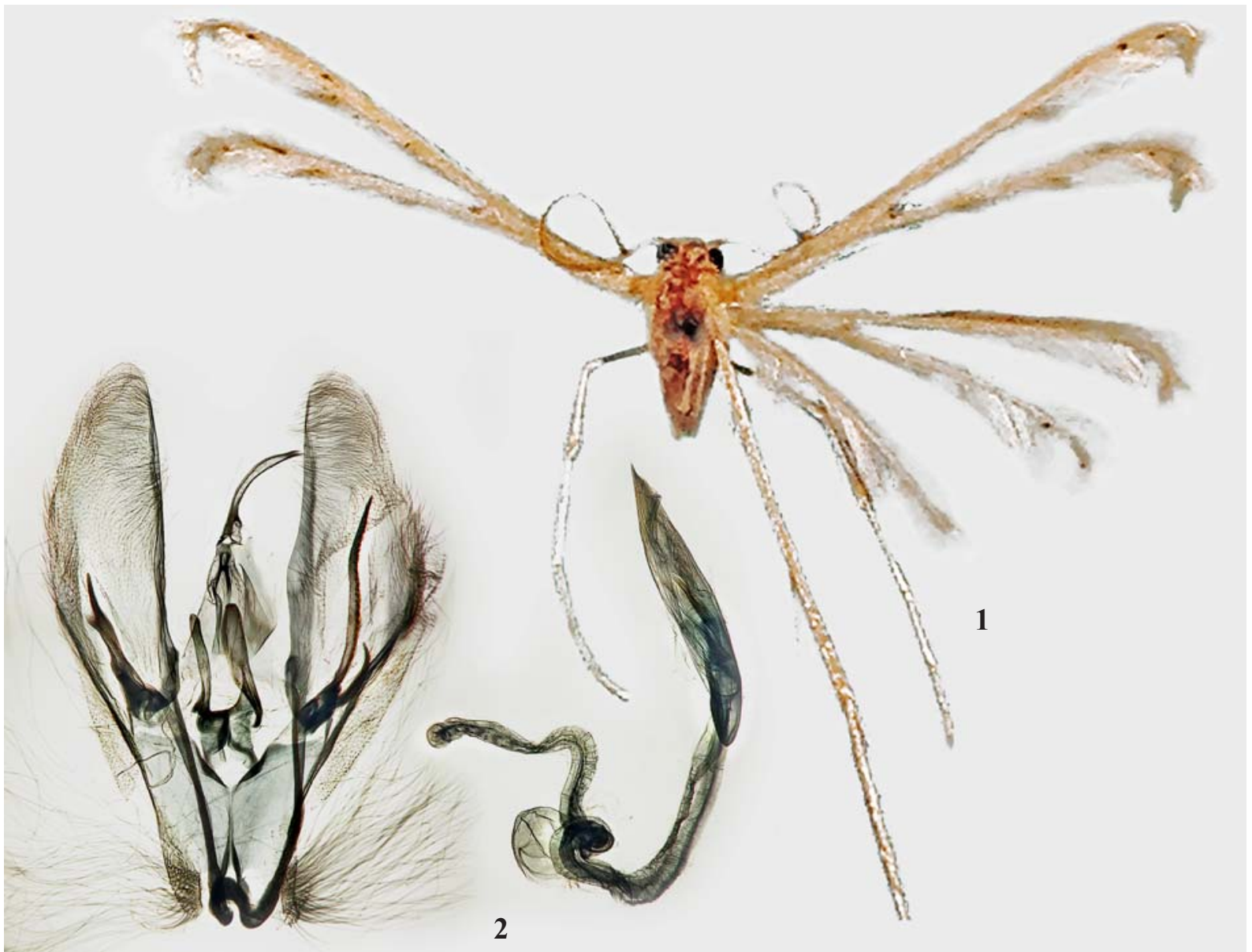

Figs 1-2. Pterophorus dohertyi, sp.n., male, holotype: 1 - habitus; 2 - male genitalia (BMNH gen.pr. 22799).

Рис. 1-2. Pterophorus dohertyi, sp.n., самец, голотип: 1 - внешний вид; 2 - гениталии (BMNH gen.pr. 22799). 
portions of brown hairs medially and distally. Hind wings unicolorous, light-yellow, two small dark points only on second lobe apically. Fringe on hind wings white. Hind legs light-brown.

Male genitalia. Valves asymmetric, narrow, slightly widened in middle part, narrowing distally. Straight harpe on left valve, reaching middle of valve length, apically sharp, distally with small process. Long harpe on right valve, slightly wavy, basally with small claw-like process. Saccus horseshoe-shaped with oval cut. Anellus arms long, right arm noticeably wider than left. Uncus thin, smoothly curved medially, sharp apically. Aedeagus short, almost straight, twice shorter than valve, narrowing distally.

Female genitalia. Unknown.

DIFFERENTIAL DIAGNOSIS. In the male genitalia, in the shape of the valves and saccus, and the harpe on the right valve, the new species is similar to Pterophorus ceylonicus Ustjuzhanin et Kovtunovich, 2015, but differs by the left harpe structure: in P. ceylonicus it is forked and significantly shorter than in the new species. Besides, the new species has a claw-like process on the right valve basally.

ETYMOLOGY. The species is named after the prominent collector, traveler and zoologist William Doherty (18571901), who collected the new species.

\section{Pterophorus shevnini \\ Ustjuzhanin et Kovtunovich sp.n.} Figs 3-4.

TYPE MATERIAL: Holotype, O7, (BMNH gen.pr. 22800), [Maluku Islands], Batian, Doherty, 1892. No. Walsingham Collection. B.M. $1910-427$.
DESCRIPTION. External characters. Forehead with tightly clinging light-brown scales. Labial palpi straight, apically sharp, equal to longitudinal eye diameter. Antennae thin, brown. Thorax and tegulae light-brown. Wingspan 30 $\mathrm{mm}$. Fore wings light-yellow, lobes deeply split. Small dark spot at cleft base. Four dark spots along costa of first lobe. Small black spot on second lobe medially, significantly larger spot distally. Fringe inside cleft white with portions of brownish hairs medially. White fringe along outer edge of second lobe. Hind wings unicolorous, light-yellow, distinct dark points only on second lobe medially, distally and apically. Fringe on hind wings white. Hind legs lightbrown, with distinctively black tips.

Male genitalia. Valves symmetric, oval-elongated, slightly widened medially, noticeably narrowing distally, with claw-shaped harpes, the left process of which is thicker than right one. Saccus horseshoe-shaped, with round cut. Anellus arms short. Uncus thin, medially curved smoothly, apically sharp. Aedeagus short, almost straight, twice shorter than valve.

Female genitalia. Unknown.

DIFFERENTIAL DIAGNOSIS. In the distinctively blackened tips of the hind legs and in the position of the dark spots on the lobes of all wings, the new species is similar to Pterophorus melanopodus (Fletcher, 1907), but it is absolutely different in its genital structure. In the symmetric genitalia, the shape of the aedeagus and harpes on the valves, the species is close to P. laocaiensis Ustjuzhanin et Kovtunovich, 2015 and P. lacteipennis (Walker, 1864), but the new species differs from both of them in its claw-like harpes,

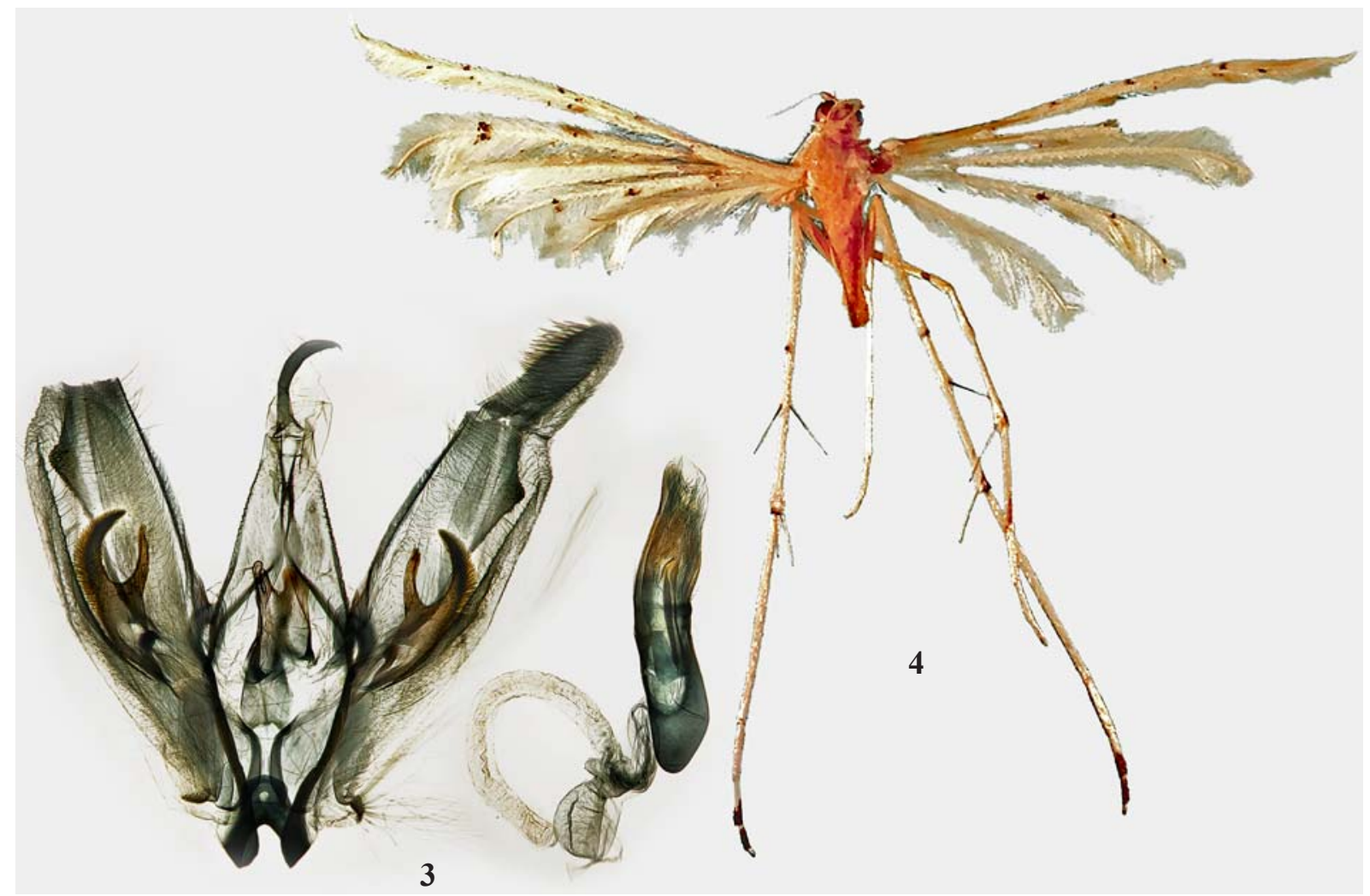

Figs 3-4. Pterophorus shevnini, sp.n., male, holotype: 3 - habitus; 4 - male genitalia (BMNH gen.pr. 22800).

Рис. 3-4. Pterophorus shevnini, sp.n., самец, голотип: 3 - внешний вид; 4 - гениталии самца (BMNH gen.pr. 22800). 
while in P. laocaiensis the harpes are forked, consisting of two wide arms, and in P. lacteipennis the harpes are robust, wide, distally forming a short fork.

ETYMOLOGY. The species is named after Evgeniy Shevnin (Novosibirsk, Russia), biologist-naturalist who has been providing assistance in our work for many years.

Acknowledgements. The authors express their deep gratitude to Mr. Kevin Tuck, the former curator of the lepidopterological collection of BMNH, London, for the possibility to work with the collection of Pterophoridae. We are also grateful to Oleg Gorbunov (Moscow, Russia) for his collected material on plume moths of the Maluku Islands.

Competing interests. The authors declare no competing interests.

\section{References}

Arenberger E. 1989. Beitrag zur Kenntnis der Indo-Australischen Pterophorus-Arten // Entomologische Zeitschrift, Frankfurt/ Main. Bd.99. S.81-88.

Arenberger E. 1995. Pterophoridae I (Pterophorinae, Ochyroticinae, Agdistinae) // Amsel H.G., Gregor F., Reisser H. (eds.). Microlepidoptera Palaearctica. Vol. 9. Karlsruhe: Verlag G. Braun GmbH. $284+296$ pp.

Gielis C. 2000. On the Genus Pterophorus Schäffer, 1766 in Indonesia (Lepidoptera: Pterophoridae) // Quadrifina. Bd.3. P.61-69.

Gielis C. 2003. Pterophoroidea and Alucitoidea // World Catalogue of Insects. Vol.4. Apollo Books: Stenstrup. 198 pp.

Ustjuzhanin P.Ya. et Kovtunovich V.N. 2010. On the Plume Moths (Lepidoptera, Pterophoridae) of Vietnam // Amurian Zoological Journal. Vol.2. No.3. P.245-248.

Ustjuzhanin P.Ya., Kovtunovich V.N. 2015. Three New Species of the Genus Pterophorus Schäffer (Lepidoptera, Pterophoridae) from the Indo-Malayan Region //Entomological Review. Vol.95. No.9. P.1251-1256. 